\title{
Effects of Normalizing Process on the Microstructural Evolution and Mechanical Properties of Low Carbon Steel Weld Metal with Niobium Addition
}

\author{
Shanping LU, Shitong WEI, Zhiquan LIU, Dianzhong LI and Yiyi LI \\ Shenyang National Laboratory for Materials Science, Institute of Metal Research, Chinese Academy of Sciences, Shenyang \\ 110016, China. E-mail: shplu@imr.ac.cn
}

(Received on July 13, 2009; accepted on November 22, 2009)

\begin{abstract}
The microstructure and mechanical properties of a $\mathrm{Nb}$ bearing weld metal under different normalizing processes had been evaluated and analyzed. The results showed that there was a great difference between the microstructure and mechanical properties of the as-welded and the as-normalized weld metals, and that the normalizing process played an important role in determining the microstructure and mechanical properties of a $\mathrm{Nb}$ bearing weld metal. The microstructure of the weld metal was converted from a columnar grain structure in the as-welded state into equiaxed grain, and the degenerated pearlite and $\mathrm{NbC}$ precipitates were observed in the weld metal after a $920^{\circ} \mathrm{C}$ normalizing treatment. Corresponding to the microstructure, the normalized weld metal had lower yield and tensile strengths, higher elongation and higher $-20^{\circ} \mathrm{C} \mathrm{im}$ pact energy than the as-welded weld metal. With the prolonging of the holding time at the normalizing temperature of $920^{\circ} \mathrm{C}$, the grain size in the weld metal remained almost constant, while the size of NbC precipitate increased. The mechanical properties of the weld metal showed no obvious change with the increasing holding time. With an increase of the normalizing temperature, the quantity of the $\mathrm{NbC}$ particles decreased and the proportion of Widmanstatten ferrite microstructure in the weld metal increased, which caused the yield and tensile strengths to increase obviously, while the elongation and impact toughness decreased significantly. When normalizing at $1200^{\circ} \mathrm{C}$, the $\mathrm{NbC}$ particles in the weld metal disappeared due to dissolution and the twin subplates were formed in the Widmanstatten ferrite.
\end{abstract}

KEY WORDS: normalizing process; weld metal; microstructure; mechanical property; Nb-microalloyed steel.

\section{Introduction}

Currently, there is a strong demand within the steel industry to develop high strength microalloyed steels for satisfying ever increasing industrial needs, such as pipeline, automobile, bridgebuilding, and so on. ${ }^{1,2}$ Niobium, vanadium, titanium are the commonly used elements in the production of microalloyed steel. They are strong carbide forming elements. One important characteristic of these microalloy elements is that they can dissolve in the substrate at a suitable temperature, and then precipitate carbide as the temperature decreases during the hot working and cooling process. The precipitates have a great influence on the microstructure and mechanical properties of steels. The mechanical properties of low carbon steel can be improved through the single or combined addition of $\mathrm{Nb}, \mathrm{V}$ or Ti. A small addition of these microalloy elements to low carbon steels is very effective in restraining the growth of the austenite grains and inhibiting austenite recrystallization. ${ }^{3,4)}$ At present, $\mathrm{Nb}$ is widely used in the production of microalloy steel with high strength and toughness, and good weldability. As the solute $\mathrm{Nb}$ atoms or $\mathrm{NbC}$ precipitates have an effect on grain refinement and precipitation hardening, $\mathrm{Nb}$ is one of the most effective elements for improving the strength and toughness of the steels. ${ }^{5)}$ Adjusting the content of $\mathrm{Nb}$ can change the $\mathrm{C}$ partition in carbide and substrate, thus controlling the steel microstructure and mechanical properties. Yu et al. ${ }^{6)}$ proposed that, in order to precipitate $\mathrm{NbC}$ particles, the content of niobium was usually higher than $0.02 \%$ in the low carbon steels.

Niobium microalloyed steel is one of the important structure materials. The weldability determines the industrial application prospect of $\mathrm{Nb}$ microalloyed steel. The majority of previous studies concerning $\mathrm{Nb}$ steels had focused on the transformation behavior of $\mathrm{Nb}$ steels in the thermomechanical process and the effect of $\mathrm{Nb}$ on the process. ${ }^{7,8)}$ However, the effects of the heat treatment process on the microstructure and mechanical properties of a $\mathrm{Nb}$ bearing weld metal had seldom been reported. In this paper, the welding wire with a $\mathrm{Nb}$ addition was deposited on S355J2G3 steel plate. $\mathrm{Nb}$ was used as the main carbide forming element in the weld metal. The effect of a normalizing process on the precipitate distribution, pearlite structure, optical microstructure, tensile properties and impact toughness of the $\mathrm{Nb}$ bearing weld metal had been investigated systematically, and the mechanism would be discussed. This research pro- 
Table 1. Chemical compositions of the base material and welding wire (mass\%).

\begin{tabular}{cccccccccccc}
\hline Material & $\mathrm{C}$ & $\mathrm{Si}$ & $\mathrm{Mn}$ & $\mathrm{S}$ & $\mathrm{P}$ & $\mathrm{Cu}$ & $\mathrm{Nb}$ & $\mathrm{Cr}$ & $\mathrm{Ni}$ & $\mathrm{Al}$ \\
\hline Base metal & 0.14 & 0.18 & 1.10 & 0.0016 & 0.014 & 0.012 & 0.019 & 0.028 & 0.026 & 0.031 \\
Welding & & & & & & & & & & \\
wire & 0.068 & 0.94 & 1.52 & 0.004 & 0.008 & 0.082 & 0.060 & - & - & - \\
\hline
\end{tabular}

Table 2. Chemical composition of the weld metal (mass \%).

\begin{tabular}{ccccccc}
\hline $\mathrm{C}$ & $\mathrm{Si}$ & $\mathrm{Mn}$ & $\mathrm{P}$ & $\mathrm{S}$ & $\mathrm{Nb}$ & $\mathrm{O}$ \\
\hline 0.078 & 0.70 & 1.38 & 0.009 & 0.008 & 0.048 & 0.038 \\
\hline
\end{tabular}

Table 3. Normalizing processes and the states of the joints.

\begin{tabular}{cc}
\hline Number & Heat treatment processes and the states of the joints \\
\hline 0 & As-welded \\
1 & Normalizing at $920^{\circ} \mathrm{C}$ for 0.5 hours \\
2 & Normalizing at $920^{\circ} \mathrm{C}$ for 3.5 hours \\
3 & Normalizing at $920^{\circ} \mathrm{C}$ for 5 hours \\
5 & Normalizing at $1020^{\circ} \mathrm{C}$ for 2 hours \\
6 & Normalizing at $1120^{\circ} \mathrm{C}$ for 2 hours \\
7 & Normalizing at $1200^{\circ} \mathrm{C}$ for 2 hours \\
\hline
\end{tabular}

vided theoretical guidance for the design of microalloyed steel welding materials, as well as the microstructure and property controlling of $\mathrm{Nb}$ bearing weld metal.

\section{Experimental Procedures}

A low carbon $\mathrm{Nb}$ bearing steel welding wire with a diameter of $1.2 \mathrm{~mm}$ was used in the experiment to weld a $12 \mathrm{~mm}$ thick S355J2G3 (base metal) steel plate by the automatic Gas Metal Arc Welding (GMAW) process. The joint was welded by 3 pass welding and the shielding gas was $85 \% \mathrm{Ar}+15 \% \mathrm{CO}_{2}$. Table 1 gave the chemical compositions of the welding wire and the base metal. The chemical composition of the weld metal deposited by the welding wire was analyzed using chemical analysis as shown in Table 2. After welding, normalizing processes under different conditions were carried out on the welded plates as shown in Table 3.

Tensile tests of the weld metal were conducted at room temperature using a computerized tensile testing system on an Instron-type testing machine. The tensile specimens were cut from the weld metal along the welding direction as shown in Fig. 1. The specimens for the impact property testing of the weld metal were extracted from these joints transversely to the welding direction by an electrical spark wire cutting machine and machined to a dimension of $55 \mathrm{~mm} \times 10 \mathrm{~mm} \times 10 \mathrm{~mm}$. The $\mathrm{V}$ notch was machined in the

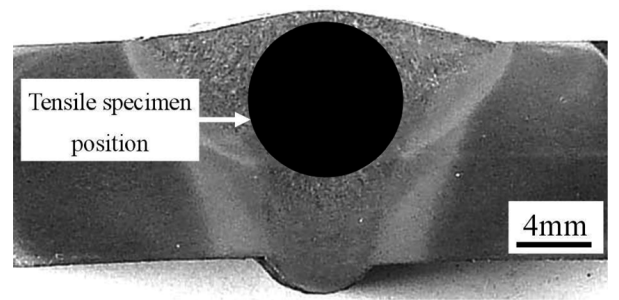

Fig. 1. The schematic diagram of the tensile specimen positions in the weld metal.

center of the weld metal on the cross section of the joints. The impact tests were conducted on the swing impacting test machine at $-20^{\circ} \mathrm{C}$. All the mechanical properties were tested three times, and the average values were calculated.

The whole microstructures of the weld metal were observed by optical microscopy. Transmission electron microscopy (TEM) was used to observe and analyze the precipitates and the fine microstructures in the weld metal. Both thin foils and carbon extraction replicas were adopted for the TEM observations. The thin foils were prepared by cutting thin wafers from the joints, and grinding to $\sim 40 \mu \mathrm{m}$ in thickness. Three millimeter discs were punched from the wafers and prepared by an argon ion thinning technique. Carbon extraction replicas were prepared by etching the polished surface in $4 \%$ nital, coating the surface with a thin film of carbon, then stripping the film and cleaning in acetone. The TEM investigations were conducted with a JEM 2010 electron microscope equipped with an energy dispersive X-ray spectroscopy (EDS) operating at $200 \mathrm{kV}$.

\section{Results and Discussion}

\subsection{Effects of the Normalizing Holding Time on the Mechanical Properties and Microstructure of the Weld Metal}

\subsubsection{Mechanical Properties}

The average yield strength (YS), tensile strength (TS), elongation and $-20^{\circ} \mathrm{C}$ impact energy of the $\mathrm{Nb}$ bearing weld metal under the normalizing condition of $920^{\circ} \mathrm{C}$ for different holding times were shown in Fig. 2. The aswelded weld metal had higher yield and tensile strengths, lower elongation and lower $-20^{\circ} \mathrm{C}$ impact energy compared with those after normalizing at $920^{\circ} \mathrm{C}$ for different holding times as shown in Figs. 2(a)-2(c), respectively. When the normalizing temperature was set at $920^{\circ} \mathrm{C}$, the 

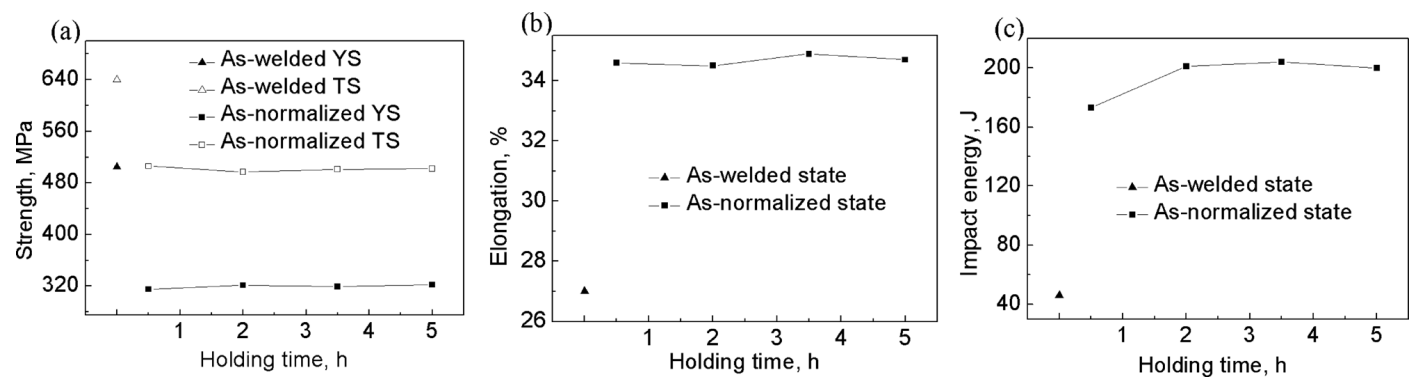

Fig. 2. Effect of normalizing holding time at $920^{\circ} \mathrm{C}$ on the mechanical properties of weld metal: (a) strength; (b) elongation; (c) $-20^{\circ} \mathrm{C}$ impact energy.

yield strength, tensile strength, elongation and $-20^{\circ} \mathrm{C}$ impact energy of the weld metal varied slightly with the increasing of the holding time from 0.5 to $5 \mathrm{~h}$.

\subsubsection{Microstructure}

The optical microstructures of the weld metal in the aswelded state and after normalizing at $920^{\circ} \mathrm{C}$ for different holding times were presented in Fig. 3. The as-welded weld metal consisted of Widmanstatten ferrite (WF), pro-eutectoid ferrite (PF), and acicular ferrite (AF) as shown in Fig. 3(a). Lee et al. ${ }^{9)}$ and Manohar et al. ${ }^{10)}$ proposed that small addition of $\mathrm{Nb}$ in steel could increase the WF and AF proportions, and decrease the PF proportion. Figures 3(b)-3(e) showed the microstructural evolution of weld metal at $920^{\circ} \mathrm{C}$ for different normalizing holding times. After normalizing at $920^{\circ} \mathrm{C}$ for $0.5 \mathrm{~h}$, the WF disappeared and the microstructure of the weld metal transformed into equiaxed ferrite and pearlite, but the as-welded columnar structure orientation still remained together with the characteristic of an incomplete normalizing structure due to the short holding time (Fig. 3(b)). With the prolonging of the normalizing holding time to $2 \mathrm{~h}$ at $920^{\circ} \mathrm{C}$, the as-welded columnar structure orientation in the weld metal disappeared completely (Fig. 3(c)). The microstructure of the weld metal presented the complete normalizing structure because of the relatively longer holding time. The columnar ferrite in the as-welded state changed into equiaxed grains. When the holding time was further prolonged to 3.5 and $5 \mathrm{~h}$ at $920^{\circ} \mathrm{C}$ (Figs. 3(d) and $3(\mathrm{e})$ ), the ferrite grains in the weld metal had grown little when compared with the microstructure treated at $920^{\circ} \mathrm{C}$ for $2 \mathrm{~h}$ (Fig. 3(c)).

According to Fig. 3, the weld metal in the as-welded and as-normalized (normalizing at $920^{\circ} \mathrm{C}$ for different holding times) states had different microstructures. A higher proportion of WF microstructure would improve the strength of the weld metal, and deteriorate its plasticity and toughness. Therefore, the as-welded Nb-bearing weld metal had higher yield and tensile strengths (Fig. 2(a)), and lower elongation (Fig. 2(b)) and lower $-20^{\circ} \mathrm{C}$ impact energy (Fig. 2(c)) as compared with the weld metal normalized at $920^{\circ} \mathrm{C}$. Under the normalizing condition of $920^{\circ} \mathrm{C}$, the microstructure of the weld metal showed no obvious change with different holding times. Therefore, the yield strength, tensile strength, elongation and $-20^{\circ} \mathrm{C}$ impact energy of the weld metal changed only slightly with an increase of the normalizing holding time at $920^{\circ} \mathrm{C}$, as shown in Fig. 2 .

The TEM was used to directly observe the precipitates in the carbon extraction replicas of the weld metal in the as-
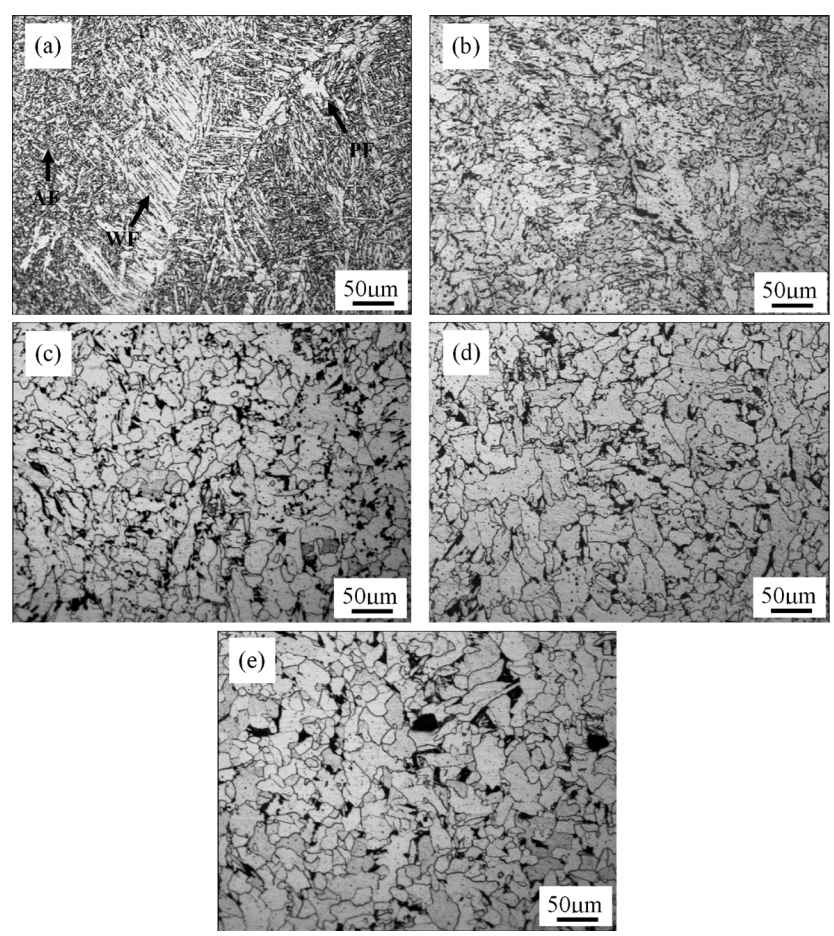

Fig. 3. Microstructures of as-welded weld metal (a) and as-normalized weld metal normalized at $920^{\circ} \mathrm{C}$ for (b) $0.5 \mathrm{~h}$; (c) $2 \mathrm{~h}$; (d) $3.5 \mathrm{~h}$; and (e) $5 \mathrm{~h}$.

welded and as-normalized (normalizing at $920^{\circ} \mathrm{C}$ for different holding times) states, as shown in Fig. 4. No precipitates were found in the as-welded weld metal (Fig. 4(a)) because of the rapid cooling rate after welding, while some precipitates were observed in the as-normalized weld metal (Figs. 4(b)-(e)) due to the normalizing effect. Under the normalizing condition of $920^{\circ} \mathrm{C}$ for different holding times, the quantity and size of the precipitates in the weld metal were different. After normalizing at $920^{\circ} \mathrm{C}$ for $0.5 \mathrm{~h}$, fine precipitates were observed in the weld metal as shown in Fig 4(b), the average size of the precipitates was $\sim 14 \mathrm{~nm}$. With the prolonging of the normalizing holding time to $2 \mathrm{~h}$ at $920^{\circ} \mathrm{C}$, the quantity and size of the precipitates in the weld metal increased due to the relatively longer holding time, as shown in Fig. 4(c). The average size of the precipitates with this normalizing condition was $\sim 21 \mathrm{~nm}$ and the precipitates were inclined to aggregation. When the holding time was further prolonged to $3.5 \mathrm{~h}$ at $920^{\circ} \mathrm{C}$, the quantity of the precipitates in the weld metal decreased, while the size of the precipitates increased to an average size of $\sim 29 \mathrm{~nm}$, and the precipitates still presented a gathering 

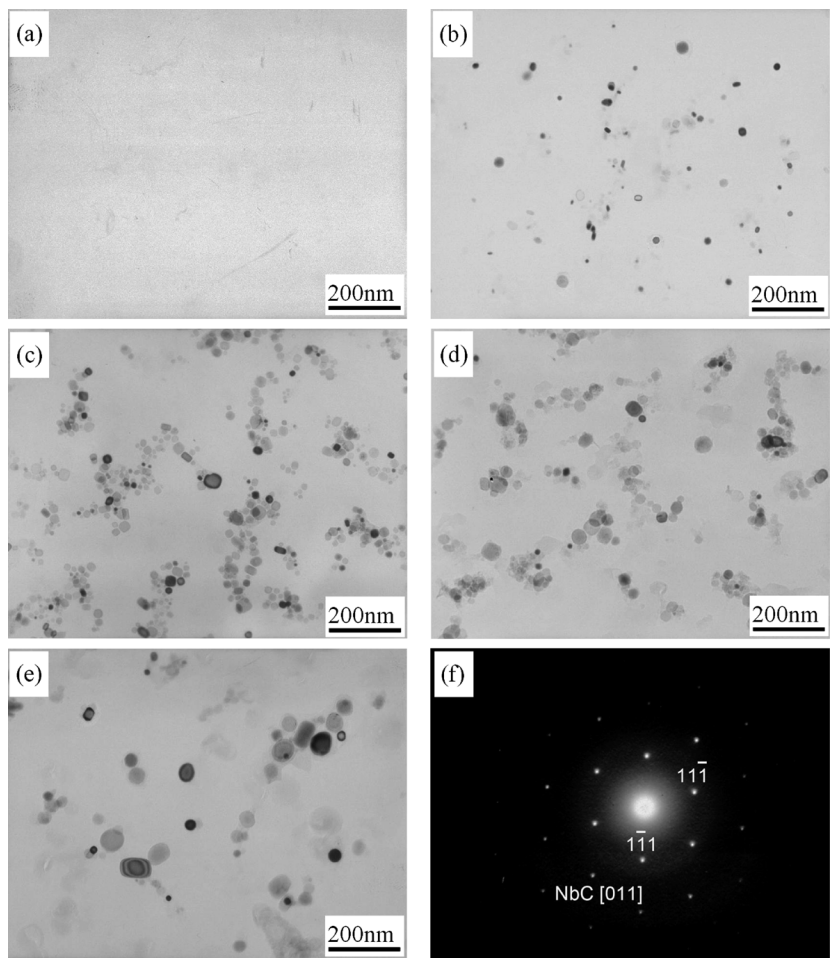

Fig. 4. TEM micrographs of the carbon extraction replica of aswelded weld metal (a) and as-normalized weld metal normalized at $920^{\circ} \mathrm{C}$ for (b) $0.5 \mathrm{~h}$; (c) $2 \mathrm{~h}$; (d) $3.5 \mathrm{~h}$; and (e) $5 \mathrm{~h}$; (f) SAED pattern of the precipitates.

trend as shown in Fig. 4(d). When the normalizing holding time was set at $5 \mathrm{~h}$, the quantity of the precipitates in the weld metal decreased further, and the size of the precipitates increased to $\sim 41 \mathrm{~nm}$, as shown in Fig. 4(e). Selected area electron diffraction (SAED) patterns were taken to identify these precipitates. They were confirmed as $\mathrm{NbC}$ particles with the $f c c$ crystal structure as shown in Fig. 4(f). Through observing the quantity, size and distribution of the $\mathrm{NbC}$ particles at the normalizing condition of $920^{\circ} \mathrm{C}$ for different holding times, the aggregation growth mode of $\mathrm{NbC}$ particles was confirmed. The different quantities and sizes of the $\mathrm{NbC}$ particles forming at the normalizing condition of $920^{\circ} \mathrm{C}$ for the different holding times from 0.5 to $5 \mathrm{~h}$ had no obvious influence on the mechanical properties (Fig. 2) and optical microstructures (Fig. 3) of the Nb bearing weld metal.

Representative bright field TEM micrographs of the pearlite microstructure in the $\mathrm{Nb}$ bearing weld metal normalizing at $920^{\circ} \mathrm{C}$ for different holding times were presented in Fig. 5. With an increase of the normalizing holding time, the pearlite morphology showed no obvious change. The weld metal normalized at $920^{\circ} \mathrm{C}$ for $0.5 \mathrm{~h}$ contained lamellar pearlite (Fig. 5(a)) and degenerated pearlite (Fig. 5(b)). Ohmori ${ }^{11)}$ named the colony of non-parallel and broken up cementite platelets in ferrite matrix as degenerated pearlite. When the normalizing holding time was prolonged to $2 \mathrm{~h}$, the lamellar pearlite (Fig. 5(c)) and degenerated pearlite (Fig. 5(d)) were also observed in the weld metal. When the normalizing holding time was set at $3.5 \mathrm{~h}$, the weld metal also contained degenerated pearlite (Fig. 5(e)). The SAED pattern of the degenerated pearlite (Fig. 5(e)) was presented in Fig. 5(f), which showed an orienta-
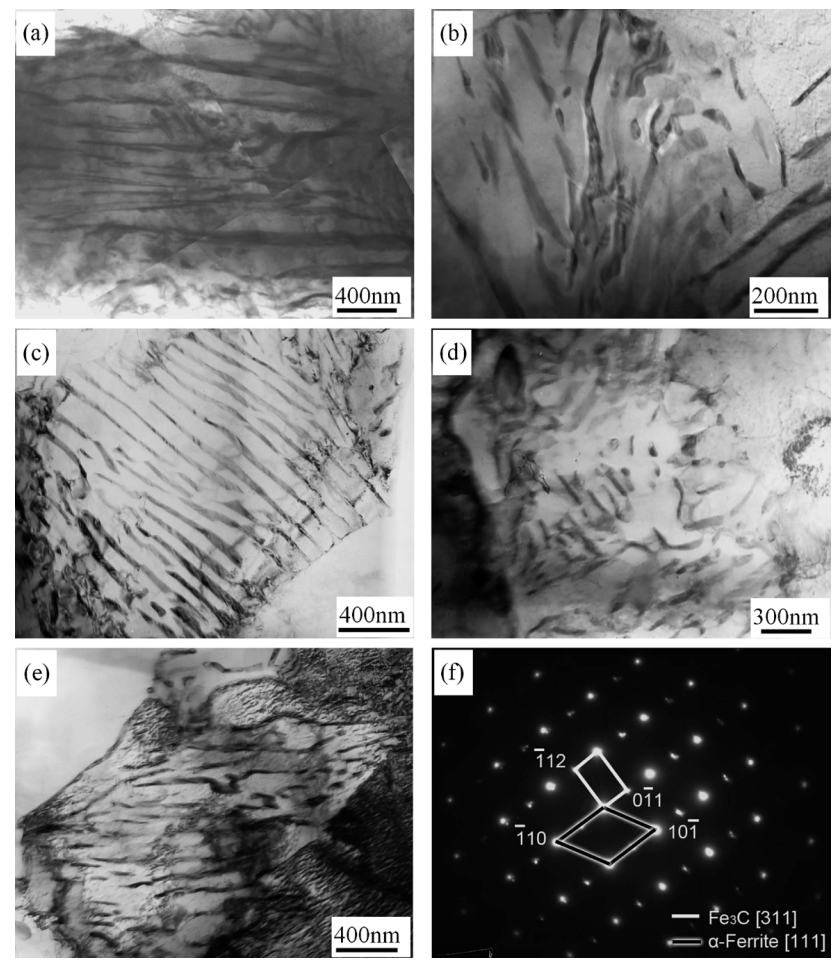

Fig. 5. Bright field TEM micrographs of the pearlite microstructure in $\mathrm{Nb}$ bearing weld metal normalized at $920^{\circ} \mathrm{C}$ for (a) $0.5 \mathrm{~h}$, lamellar pearlite; (b) $0.5 \mathrm{~h}$, degenerated pearlite; (c) $2 \mathrm{~h}$, lamellar pearlite; (d) $2 \mathrm{~h}$, degenerated pearlite; (e) $3.5 \mathrm{~h}$, degenerated pearlite; (f) SAED pattern of degenerated pearlite showing orientation relationship between cementite and ferrite.

tion relationship between the cementite and ferrite: $(110)_{\mathrm{Fe}} / /$ $(0 \overline{1} 1)_{\mathrm{Fe}_{3} \mathrm{C}},(\overline{1} \overline{1} 2)_{\mathrm{Fe}} / /(\overline{1} 12)_{\mathrm{Fe}_{3} \mathrm{C}}$, and $[111]_{\mathrm{Fe}} / /[311]_{\mathrm{Fe}_{3} \mathrm{C}}$.

Ohmori ${ }^{11)}$ proposed that degenerated pearlite was formed by nucleation of cementite at the interface between the ferrite and austenite, followed by carbide free ferrite layers enclosing the cementite particles in the transformation temperature range between normal pearlite and upper bainite. Similar to lamellar pearlite, degenerated pearlite was also formed by a diffusion process. Its different morphology was attributed to insufficient carbon diffusion to develop continuous lamellae. In this experiment, the normalizing process was conducted to the weld metal. The fast air cooling rate during the normalizing cooling process caused insufficient carbon diffusion to develop continuous lamellae at some positions of the weld metal, then degenerated pearlite was formed finally. Addition of $\mathrm{Nb}$ to the weld metal was beneficial to the formation of degenerated pearlite, because the strong affinity of $\mathrm{Nb}$ and $\mathrm{C}$ made the $\mathrm{C}$ diffusion more difficult to form continuous lamellae, which was similar to the results in the $\mathrm{Nb}$ bearing steel reported by Shanmugam et $a l .{ }^{12)}$ Yamane $e a{ }^{13)}$ believed that as a microstructural constituent, degenerated pearlite could promote the toughness of steel.

\subsection{Effects of Normalizing Temperature on the Me- chanical Properties and Microstructure of the Weld Metal}

\subsubsection{Mechanical Properties}

When the normalizing holding time was kept at $2 \mathrm{~h}$ and the temperature was set at $920^{\circ} \mathrm{C}, 1020^{\circ} \mathrm{C}, 1120^{\circ} \mathrm{C}$ and 

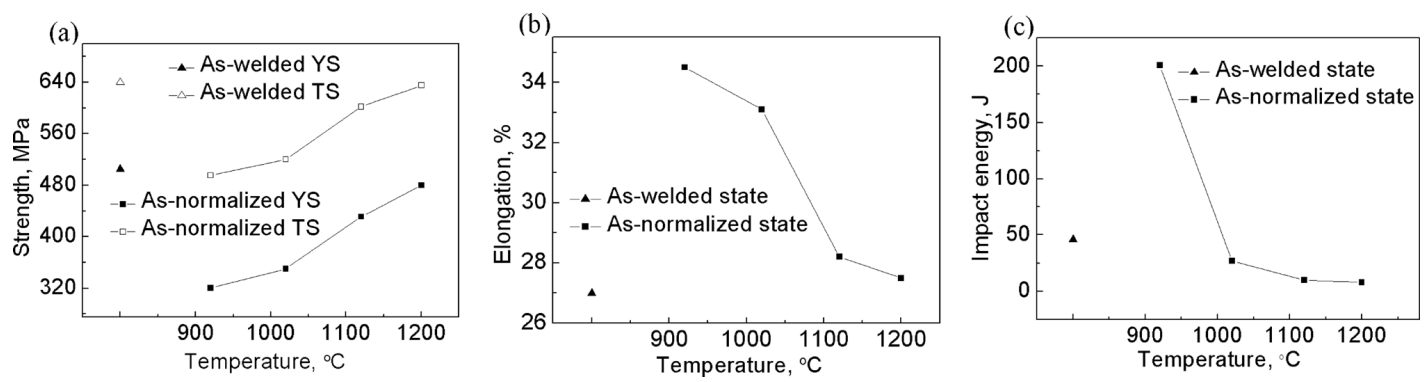

Fig. 6. Effect of normalizing temperature on the mechanical properties of the weld metal: (a) strength; (b) elongation; (c) $-20^{\circ} \mathrm{C}$ impact energy.

$1200^{\circ} \mathrm{C}$, respectively, the yield strength, tensile strength, elongation and $-20^{\circ} \mathrm{C}$ impact energy of the weld metal as a function of normalizing temperature were shown in Figs. 6(a)-6(c), respectively. When the normalizing temperature was $920^{\circ} \mathrm{C}$, the yield and tensile strengths of the weld metal were lower than those of the as-welded weld metal, while the elongation and the $-20^{\circ} \mathrm{C}$ impact energy of the weld metal were higher than those of the as-welded weld metal. Furthermore, with an increase of the normalizing temperature, the yield and tensile strengths increased obviously (Fig. 6(a)), while the elongation and $-20^{\circ} \mathrm{C}$ impact energy decreased significantly (Figs. 6(b) and 6(c)). In order to explain the variations of the mechanical properties of the $\mathrm{Nb}$ bearing weld metal with the normalizing parameters, a microstructure analysis of the weld metal was necessary.

\subsubsection{Microstructure}

The optical microstructure of the weld metal in the aswelded state and after normalizing at different temperatures for $2 \mathrm{~h}$ was presented in Fig. 7. The proportion of Widmanstatten ferrite (WF) microstructure in the weld metal increased with the increasing normalizing temperature as shown in Figs. 7(b)-7(e). After normalizing at $920^{\circ} \mathrm{C}$ for $2 \mathrm{~h}$, the microstructure of the weld metal transformed from the as-welded structure into equiaxed ferrite and pearlite (Fig. 7(b)), and no WF was found at this normalizing temperature. When the normalizing temperature increased from 920 to $1020^{\circ} \mathrm{C}$, the grain size of the ferrite clearly increased and partial WF was observed in the weld metal (Fig. 7(c)). The austenite grain size was larger when the weld metal was normalized at higher temperature. The larger austenite grain size increased the austenite stability and the grain size of the transformed phase. When the austenite grain size was larger and the cooling rate was suitable, WF transformation would happen. $\mathrm{Nb}$ addition in the weld metal could also increase the austenite stability and promote the formation of WF. During the normalizing cooling process, the solute $\mathrm{Nb}$ would segregate to the austenite grain boundaries, decrease the grain boundary energy, and suppress the nucleation of $\mathrm{PF}$ at austenite grain boundaries. Furthermore, the strong affinity of $\mathrm{Nb}$ and $\mathrm{C}$ made the $\mathrm{C}$ diffusion difficult, and lowered the advancing rate of austenite and ferrite phase boundaries. The solute drag effect of $\mathrm{Nb}$ would also restrain the generation of $\mathrm{PF}$ which formed at higher temperatures, and promote the generation of WF which formed at lower temperatures. When the normalizing temperature was $1020^{\circ} \mathrm{C}$, some austenite grains met the WF formation condition, and transformed into WF
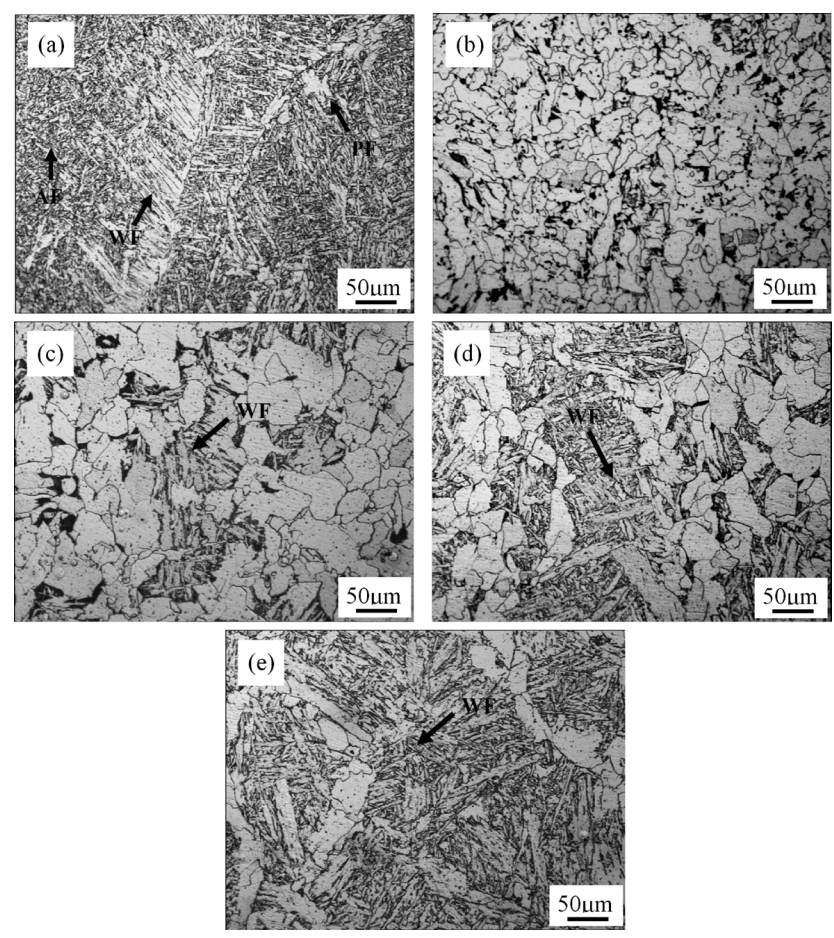

Fig. 7. Microstructures of as-welded weld metal (a) and the weld metals normalized for $2 \mathrm{~h}$ at (b) $920^{\circ} \mathrm{C}$; (c) $1020^{\circ} \mathrm{C}$; (d) $1120^{\circ} \mathrm{C}$; and (e) $1200^{\circ} \mathrm{C}$.

finally. When the normalizing temperature was raised to 1120 and $1200^{\circ} \mathrm{C}$, most of the austenite grains in the weld metal became larger and satisfied the WF formation condition. Eventually, the majority of the weld metal changed into WF, the remainder converted into equiaxed ferrite (Figs. 7(d) and 7(e)).

The weld metals in the as-welded and as-normalized (normalizing at different temperatures for $2 \mathrm{~h}$ ) states had obviously different microstructures (Fig. 7), which resulted in differences in the mechanical properties of the weld metal. The higher proportion of Widmanstatten ferrite microstructure caused higher yield and tensile strengths (Fig. 6(a)), lower elongation (Fig. 6(b)) and lower $-20^{\circ} \mathrm{C}$ impact energy (Fig. 6(c)) in the as-welded weld metal, as compared with the weld metal normalizing at $920^{\circ} \mathrm{C}$ for $2 \mathrm{~h}$. With the increase of the normalizing temperature, the increasing proportion of WF microstructure in the weld metal improved the yield and tensile strength and deteriorated the elongation and impact energy of the weld metal. Therefore, for the $\mathrm{Nb}$ bearing weld metal, with the increase of the normalizing temperature, the yield and tensile strengths definitely 

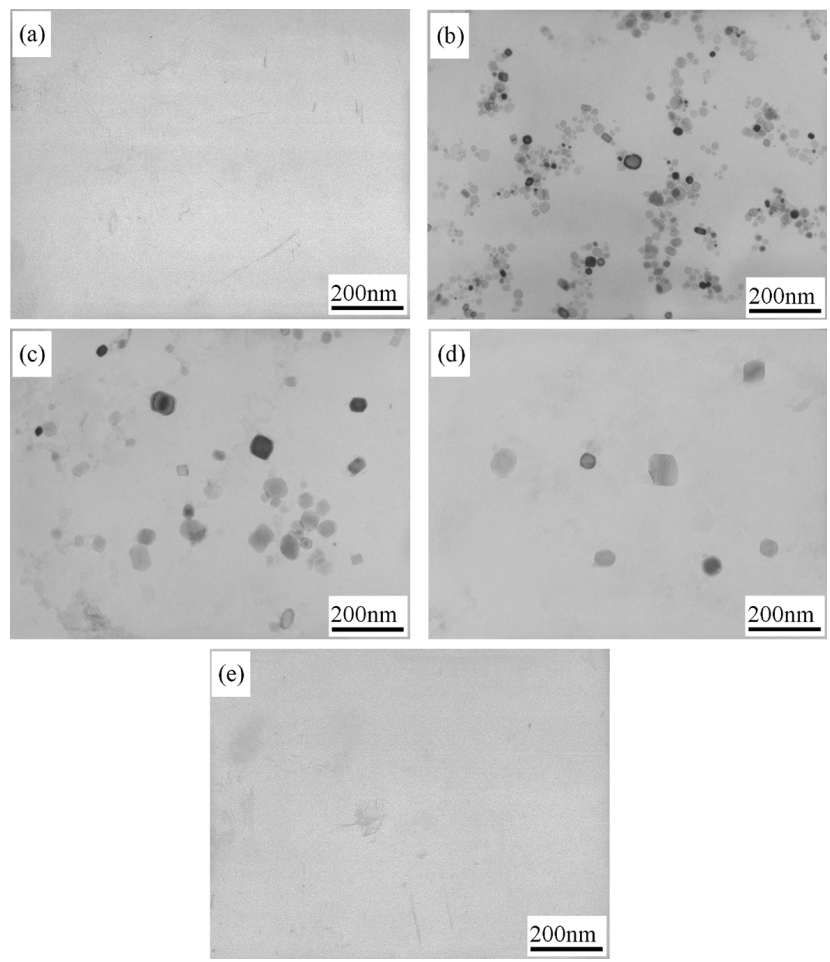

Fig. 8. TEM micrographs of the carbon extraction replica of aswelded weld metal (a) and the weld metals normalized for $2 \mathrm{~h}$ at (b) $920^{\circ} \mathrm{C}$; (c) $1020^{\circ} \mathrm{C}$; (d) $1120^{\circ} \mathrm{C}$; and (e) $1200^{\circ} \mathrm{C}$.

increased (Fig. 6(a)), while the elongation and $-20^{\circ} \mathrm{C}$ impact energy decreased significantly (Figs. 6(b) and 6(c)).

To further analyze the existing forms of the $\mathrm{Nb}$ in the weld metal after normalizing at different temperatures, carbon extraction replicas of the Nb-bearing weld metal under different normalizing temperature for $2 \mathrm{~h}$ were observed using TEM and the results were shown in Fig. 8. Under different normalizing temperatures for $2 \mathrm{~h}$, the quantity and size of the precipitates in the weld metal changed obviously. No precipitates were found in the as-welded weld metal (Fig. 8(a)) because of the rapid cooling rate after welding. Under the normalizing condition of $920^{\circ} \mathrm{C}$ for $2 \mathrm{~h}$, many $\mathrm{NbC}$ precipitates were observed in the weld metal (Fig. 8(b)), which were confirmed by both SAED and EDX. The average size of the precipitates under this normalizing condition was $\sim 21 \mathrm{~nm}$ and the precipitates were apt to aggregate together. With the increase of the normalizing temperature, the size of the precipitates increased, while the quantity of the precipitates decreased (Figs. 8(c) and 8(d)). The $\mathrm{NbC}$ precipitates were apt to coarsen at higher temperatures. The average sizes of the precipitates at the normalizing temperatures of $1020^{\circ} \mathrm{C}$ and $1120^{\circ} \mathrm{C}$ were $\sim 43 \mathrm{~nm}$ and $\sim 56 \mathrm{~nm}$, respectively. When the normalizing temperature was further raised to $1200^{\circ} \mathrm{C}$, the $\mathrm{NbC}$ precipitate was hardly found in the $\mathrm{Nb}$ bearing weld metal as shown in Fig. 8(e). The NbC precipitates would dissolve into the substrate when the normalizing temperature exceeded the solid solution temperature of $\mathrm{NbC}$, which was below $1200^{\circ} \mathrm{C}$ according to Hong et al. ${ }^{14)}$ and Li et al. ${ }^{15)}$

TEM micrographs of the pearlite microstructure in the $\mathrm{Nb}$ bearing weld metal normalized at different temperatures for $2 \mathrm{~h}$ were presented in Fig. 9. Both the weld metals normalizing at $1020^{\circ} \mathrm{C}$ and $1120^{\circ} \mathrm{C}$ contained lamellar
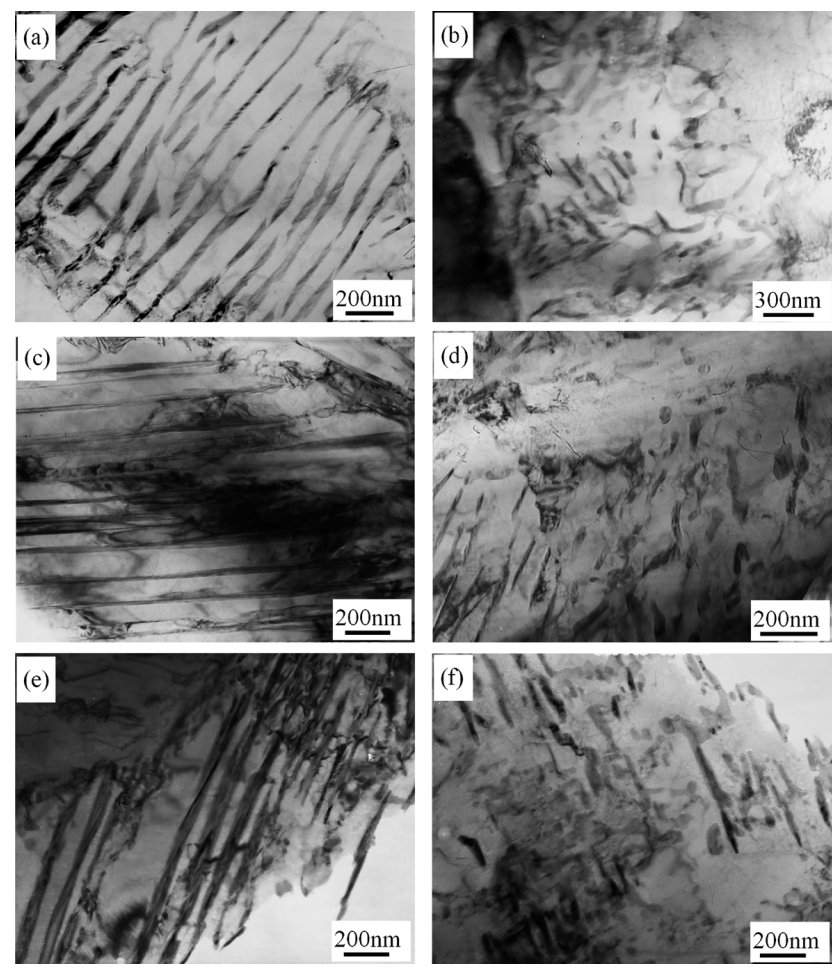

Fig. 9. TEM micrographs of the pearlite microstructure in $\mathrm{Nb}$ bearing weld metal normalized at different temperatures for $2 \mathrm{~h}$ : (a) lamellar pearlite normalized at $920^{\circ} \mathrm{C}$; (b) degenerated pearlite normalized at $920^{\circ} \mathrm{C}$; (c) lamellar pearlite normalized at $1020^{\circ} \mathrm{C}$; (d) degenerated pearlite normalized at $1020^{\circ} \mathrm{C}$; (e) lamellar pearlite normalized at $1200^{\circ} \mathrm{C}$; (f) degenerated pearlite normalized at $1200^{\circ} \mathrm{C}$.
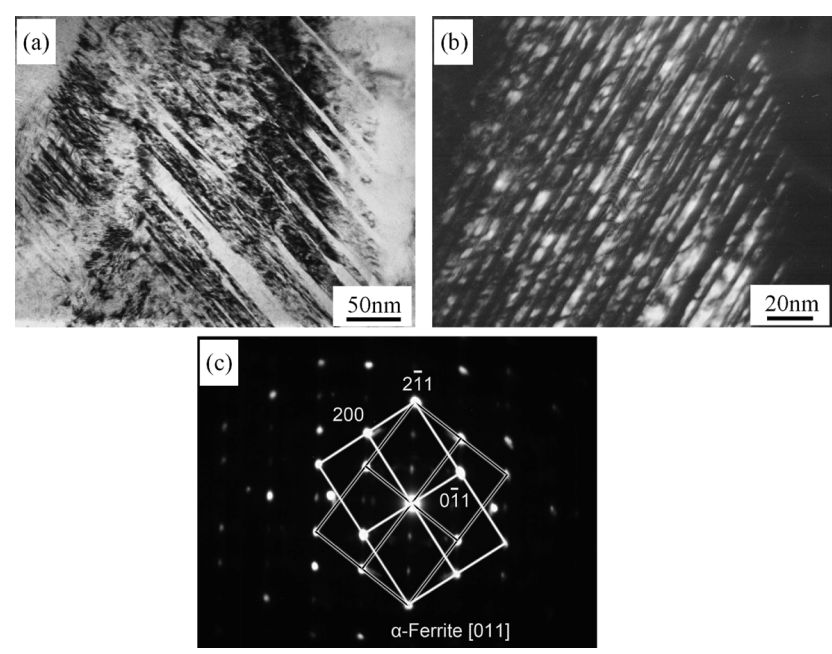

Fig. 10. TEM micrographs of the WF in the weld metal normalized at $1200^{\circ} \mathrm{C}$ for $2 \mathrm{~h}$ : (a) bright field image; (b) high magnification dark field image; (c) corresponding SAED pattern.

pearlite (Figs. 9(c) and 9(e)) and degenerated pearlite (Figs. 9(d) and 9(f)) just like the weld metal normalizing at $920^{\circ} \mathrm{C}$ due to the similar cooling condition.

Representative TEM micrographs of the Widmanstatten ferrite (WF) microstructure in the $\mathrm{Nb}$ bearing weld metal normalized at $1200^{\circ} \mathrm{C}$ for $2 \mathrm{~h}$ were shown in Fig. 10. Figure 10(a) showed that the WF contained thin and mutual parallel ferrite subplates. The high magnification dark field image of the ferrite subplates was shown in Fig. 10(b), 
which indicated the widths of the ferrite subplates were in the range of $1-11 \mathrm{~nm}$. The SAED pattern obtained for the ferrite subplates indicated twin orientation relationship between different ferrite subplates, as shown in Fig.10(c). Similar to the bainite transformation, the forming of WF was also controlled by the shear mechanism and the diffusion of solute atoms during the transformation. The shearing deformation during the phase transformation process was the reason for the formation of twinned ferrite subplates in the WF.

\section{Conclusions}

The $\mathrm{Nb}$ bearing weld metal was normalized at 920 , 1020,1120 , and $1200^{\circ} \mathrm{C}$ for different holding times, and its mechanical properties and microstructural evolution were evaluated and analyzed. From this research the following conclusions were drawn:

(1) The microstructure and mechanical properties of the $\mathrm{Nb}$ bearing weld metal were significantly affected by the normalizing process.

(2) After the normalizing treatment at $920^{\circ} \mathrm{C}$, the microstructure of the weld metal converted from columnar grains in the as-welded state into equiaxed grains. Accordingly, when compared with the as-welded weld metal, the as-normalized weld metal had lower yield and tensile strengths, higher elongation and higher $-20^{\circ} \mathrm{C}$ impact energy. Furthermore, degenerated pearlite and $\mathrm{NbC}$ precipitates were observed in the as-normalized weld metal.

(3) With the prolonging of the holding time at the normalizing temperature of $920^{\circ} \mathrm{C}$, the size of the $\mathrm{NbC}$ precipitate increased, while the optical microstructure in the weld metal showed no significant change. Corresponding to the microstructure, the mechanical properties of the weld metal remained almost unchanged with the increasing holding time.

(4) With an increase of the normalizing temperature, the proportion of WF microstructure in the weld metal increased, which caused an increase in the yield and tensile strengths of the weld metal, while the elongation and $-20^{\circ} \mathrm{C}$ impact energy decreased significantly. Furthermore, the quantity of the $\mathrm{NbC}$ particles in the $\mathrm{Nb}$ bearing weld metal decreased as the normalizing temperature increases.

(5) After normalizing at $1200^{\circ} \mathrm{C}$, the $\mathrm{NbC}$ particles in the weld metal disappeared due to the dissolution and the twin orientation relationship among the thin ferrite subplates in the WF was found.

\section{Acknowledgement}

The authors are grateful for the financial support from the National Key Technologies R\&D Program of China under Grant No. 2009BAG12A07-D06 and National Science Foundation of China (NSFC) under Grant No. 50874101.

\section{REFERENCES}

1) S. Shanmugam, N. K. Ramisetti, R. D. K. Misra, J. Hartmann and S. G. Jansto: Mater. Sci. Eng. A, A478 (2008), 26.

2) S. Hashimoto, S. Ikeda, K. Sugimoto and S. Miyake: ISIJ Int., 44 (2004), 1590.

3) Y. Q. Zhang, H. Q. Zhang, W. M. Liu and H. Hou: Mater. Sci. Eng. A, $\mathbf{A 4 9 9}$ (2009), 182.

4) E. V. Pereloma, I. B. Timokhina, K. F. Russell and M. K. Miller: Scr. Mater, 54 (2006), 471.

5) J. S. Park and Y. K. Lee: Scr. Mater, 57 (2007), 109.

6) Q. B. Yu, Z. D. Wang, X. H. Liu and G. D. Wang: Mater. Sci. Eng. A, A379 (2004), 384.

7) S. Shanmugam, N. K. Ramisetti, R. D. K. Misra, T. Mannering, D. Panda and S. Jansto: Mater. Sci. Eng. A, A460-461 (2007), 335.

8) E. V. Pereloma, I. B. Timokhina and P. D. Hodgson: Mater. Sci. Eng. A, A273-275 (1999), 448.

9) K. J. Lee, J. K. Lee, K. B. Kang and O. Kwon: ISIJ Int., 32 (1992), 326.

10) P. A. Manohar, T. Chandra and C. R. Killmore: ISIJ Int., 36 (1996), 1486.

11) Y. Ohmori: Trans. Iron Steel Inst. Jpn., 11 (1971), 339.

12) S. Shanmugam, R. D. K. Misra, T. Mannering, D. Panda and S. G. Jansto: Mater. Sci. Eng. A, A437 (2006), 436.

13) T. Yamane, K. Hisayuki, Y. Yawazu, T. Takahashi, Y. Kimura and S. Tsukuda: J. Mater. Sci., 37 (2002), 3875.

14) S. C. Hong, S. H. Lim, H. S. Hong, K. J. Lee, D. H. Shin and K. S. Lee: Mater. Sci. Eng. A, $\mathbf{A 3 5 5}$ (2003), 241.

15) Y. Li, J. A. Wilson, D. N. Crowther, P. S. Mitchell, A. J. Craven and T. N. Baker: ISIJ Int., 44 (2004), 1093. 